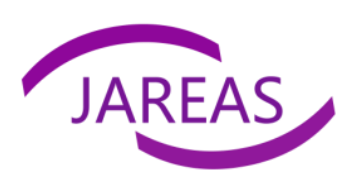

Journal of Advanced Research in Economics and Administrative Sciences

Website: https://bcsdjournals.com/index.php/jareas

ISSN 2708-9320 (Print) and 2709-0965 (Online)

Vol.2, Issue 1, 2021

DOI: https://doi.org/10.47631/jareas.v2i1.212

\title{
The Role of FDI Inflow in Economic Growth: Evidence from Developing Countries
}

\author{
Cao Liang ${ }^{1}$, Salman Ali Shah ${ }^{2}$, Tian Bifei ${ }^{3}$ \\ ${ }^{1}$ Professor, School of Business Administration, Zhongnan University of Economics and Law, Wuhan, \\ China.Email: frankcao@126.com \\ ${ }^{2}$ PhD Scholar, School of Business Administration, Zhongnan University of Economics and Law, Wuhan, \\ China.Email:salmanali.eco@gmail.com \\ ${ }^{3}$ Professor, School of Business Administration, Zhongnan University of Economics and Law, Wuhan, \\ China.Email: tianbifei@foxmail.com
}

\begin{tabular}{|c|c|}
\hline Article Info & Abstract \\
\hline $\begin{array}{l}\text { Article history: } \\
\text { Received: } 18 \text { December } 2020\end{array}$ & $\begin{array}{l}\text { Purpose: This study is carried out to study the relationship between FDI and } \\
\text { economic growth of developing countries. }\end{array}$ \\
\hline Revised: 13 February 2021 & Approach/Methodology/ Design: The study used data from 2000 to 2019 for \\
\hline Accepted: 14 February 2021 & $\begin{array}{l}113 \text { developing and transition countries. The study used Hausman fixed effect } \\
\text { and instrumental variables two stage least square region to trace the results. }\end{array}$ \\
\hline $\begin{array}{l}\text { Keywords: } \\
\text { FDI; Economic Growth; } \\
\text { Developing Countries }\end{array}$ & $\begin{array}{l}\text { Findings: The result of the study found a positive relationship between FDI } \\
\text { and economic growth. An increase in FDI inflow will result and upsurge in } \\
\text { economic growth of developing country. The relationship between } \\
\text { unemployment and economic growth is found negative. The overall results }\end{array}$ \\
\hline $\begin{array}{l}\text { JEL: O4, D2, D24 } \\
\text { Paper Type : }\end{array}$ & $\begin{array}{l}\text { show that FDI and economic growth has a positive relationship in developing } \\
\text { countries. }\end{array}$ \\
\hline Research Article & $\begin{array}{l}\text { Practical Implication: This study used annual data of pre pandemic. It is } \\
\text { concluded in the study that future studies have to check the impact in post }\end{array}$ \\
\hline $\begin{array}{l}\text { Corresponding Author: } \\
\text { Salman Ali Shah } \\
\text { Email: } \\
\text { salmanali.eco@gmail.com }\end{array}$ & $\begin{array}{l}\text { pandemic scenario. } \\
\text { Originality/Value: Though the relationship between FDI and economic } \\
\text { growth is studied widely in different studies. As mentioned that COVID-19 } \\
\text { pandemic changed the world economic situation there is much more aspects } \\
\text { of FDI and economic growth is remaining to study. The issue of FDI and } \\
\text { economic growth for a cluster of } 113 \text { countries is addressed in this study. }\end{array}$ \\
\hline
\end{tabular}

\section{Introduction}

Why are people in richer countries richer than others? Or why are some countries richer than others? The most significant question in the study is growth. Growth related studies answers such questions by developing models through numerical data. GDP per capita is declared a crucial indicator of economic growth in different growth studies and theories. Romer (1994) emphasizes on living standard as a portion of his initial incentive for endogenous growth models. Kremer (1993) indicates the rushing in population growth. Several models have been developed to describe the motionless living standard of thousands of years ago to the new economic growth era. One of the crucial factors included in all these models is "Malthusian diminishing returns." The collection of growth facts is gathered best in the famous work by (Solow, 1957). Kaldor (1961)Described the stylized growth facts as the stability of GDP shares paid to labour and capital. Economic growth is not tenacious actively. Some countries in the 
world see a peak while others take off, and some countries never grow. Denison (1962)declared the increase in GDP or GDP per capita is called economic growth.

Foreign direct investment is considered as a catalyst for economic growth. Developing countries have lack of advance technology, managerial practices and poor financial development system. FDI contributes to economic growth by increasing capital flow, employment creation, increase in exports and technology transfer. In the current scenario COVID-19 pandemic disturbed the world economy. The world output is declined, world unemployment level increased ultimately the overall economic circle is disturbed.

The capital accumulation is all the time determined, far extra than whole growth. Variations in capital accumulation are not associated with variation in economic growth. Economic growth and development are the main aims of every economy globally, and it is targeted in a vast number of economics studies. The main differences between developed and developing countries are factors that determine economic growth. FDI is prized by developing economies for the bundle of assets that multinational enterprises deploy with their investments. Most of these assets are intangible by nature and scarce in developing countries. These assets include technology, management, skills, and quality of the product. Overall the characterization of the FDI activities is based on three categories representing (Iamsiraroj) the type of FDI (vertical, horizontal, distribution-oriented), (Solow) the relevance of FDI experience, and (c) the importance of the firm's capacity to innovate. Vertical FDI is expected to be deployed primarily in low-cost countries. In particular wages and production costs are the lowest in Eastern Europe, Latin America, and Asia.

Transition and developing countries frequently lack the necessary capital and advancement in technology. To fulfil this gap developing and transition countries move towards foreign investment. FDI becomes a significant source of technological and progress and the necessary capital to upgrade their existing one. After 1990s, economies in the east of Europe transited from planned economies to market economies. Market forces were shown to be the critical determinants of production and resource allocation. The movement of transitions from planned to market economies and a smart set of investment atmosphere marked the foundation of immense FDI inflow in the region. This study aimed to check the impact of FDI on economic growth in developing countries. It is closely associated with pre COVID-19 impact of FDI on economic growth, and it will be helpful in comparing the impact in post COVID-19 scenario.

\section{Literature Review}

Neo-classical approaches centred studies claimed that FDI affect only income level while, it has no impact on growth in the long run (De Mello Jr (1997); Solow, 1957) Neo-classical growth theories stated that FDI inflow could add to long-run growth if it shows the appositive and permanent effect on technology. Pakistan is a developing country in the South Asian region. According to the World Bank, the share of FDI to GDP of Pakistan was recorded the lowest point is -0.06 in 1973 while the highest was recorded in 2007, which is 3.67. The percentage of

Copyright (C 2021, Journal of Advanced Research in Economics and Administrative Sciences (JAREAS), Under a Creative Commons Attribution 4.0 International License 
FDI to GDP of Pakistan in 2019 is reported at 0.8 (Sohail \& Mirza, 2020). Gudaro et al. (2012)studied the nexus between FDI and economic growth in Pakistan. The study's results show that FDI has a positive and significant impact on Pakistan's economic growth. The importance of FDI is twin, both the home and host country benefits from FDI. The home country earns a profit, and FDI inflow creates growth and development opportunities for the host country. FDI is considered a pivotal consecration to the host economy (Iamsiraroj, 2016). Tabassum et al. (2013) studied the association between FDI and the economic growth of Bangladesh's. The sample for the study is from 1972-2011. It was the first year of the country after independence. The study finds that domestic investment has a significant impact on economic growth, while FDI and trade openness have less effect on Bangladesh's economic development.

Alam and Shah (2013)investigated the potential determinants of FDI for 10 OECD member countries. The result of the study indicated that labor cost is a strong determinant of FDI. they also identified efficient policies can decrease labor costs, which will attract more FDI. subsequently. It is recongnized that low labor cost countries are the most attractive distend countries for investors from abroad.In another study Sokhanvar and Mahmoodi (2015)investigated the relationship between FDI exports and economic growth of 8 developing countries from Asia and Europe. The results indicated that European developing countries had shown bidirectional causality between FDI and GDP. The casual relationship between Asian andEuropean countries also shows a bidirectional causal relationship in the short-run. Rehman (2016)investigated FDI and economic growth in Pakistan. The study's finding indicates that FDI depends upon economic growth, but the study declared this relationship is not real. The study alsonoted that human capital, FDI, and exports are essential factors of economic growth. In Indonesia, Khaliq and Noy (2007)studied the impact of FDI on Indonesia's economic growth using sectoral data from 1997-2006. Specifically, the study demonstrated that "mining \& quarrying" sector showed a strong negative effect on FDI flow. According to this, FDI inflow and economic growth have a positive relationship. Easing restrictions to attract foreign capital flow was seen in the previous decades. Stiglitz (1999)reported that some countries are given relaxation in tax and subsidies to attract FDI.

FDI is seen as the crucial determinant of economic growth and development in both developed and developing countries. FDI increases the carry knowledge spillover to the destined economy, enhances employment, and makes more choices to the consumer in the host economy market. Sabir et al. (2019) FDI inflow plays the role of catalyst for growth and development in developing countries. India received a massive amount of FDI over the period from 1984 to 2017. Similarly, Pakistan and Sri Lanka also recorded an upsurge in gross fixed capital formation through FDI inflow(Adhikary, 2017). 


\section{Methodology and Procedures}

\section{Variables of the study}

FDI: "FDI net inflows as a percentage of GDP" the source of the data is UNCTAD and World Bank (WDI).

I) GDP growth: The money value of all final goods and services produced and marketed in the country in one year (Lea, 2019).

II) Population growth: The annual growth rate of the population overall (Ospina, 2013).

III) Trade openness: The total imports and exports as a percentage of the country's total GDP.

IV) Government consumption: Total government expenditures (developmental and non-developmental) of the government in a year (WDI, 2020)

V) Inflation: The increase in the general price level (consumer price index) of a country annually (WDI, 2020).

VI) GDP per Capita: This is the deviation of GDP divided by the total population. It is the indicator of a country's growth and development (WDI, 2020)

VII) Human capital: Total of average schooling attained per year.

VIII) GDS: Gross Domestic savings. (WDI, 2020)

IX) GFCF: Gross Fixed capital formation.“Gross fixed capital formation (formerly gross domestic fixed investment) includes land improvements (fences, ditches, drains, and so on); plant, machinery, and equipment purchases; and the construction of roads, railways, and the like, including schools, offices, hospitals, private residential dwellings, and commercial and industrial buildings" (WDI, 2020).

X) UNE: Unemployment (WDI,2020)

$$
E G=\beta_{0}+\beta_{1} F D I_{i, t}+\beta_{2} X_{i, t}+C
$$

Where

EG is economic growth (GDP per capita, GDP growth)

$\boldsymbol{\beta}_{\mathbf{0}}=$ The intercept of the model.

$\mathbf{B}_{1}=$ Estimator of the independent variable

$\boldsymbol{B}_{2}=$ Estimator of control variables

$\mathbf{E}=$ Error terms.

This study used GDP per capita and GDP growth to measure economic growth in developing economies. Human capital is declared the main source of growth in endogenous growth models. At the same time, it is also an extension of neoclassical growth models. Human growth 
contributes to economic growth and development (Barro (1991) and(Mankiw et al., 1992)Economic growth is a combination of indicators, including human capital, R\&D, and trade openness. R\&D is a vital determinant of economic growth in developing countries. R \& D's economic growth role has been stressed by different models of endogenous models in economics. Some of the studies replaced it with innovation. The association between R\&D and economic growth in developing countries has been confirmed by different studies (Fagerberg \& Sollie, 1987).

\section{Countries in the sample}

The study draws data from "Albania, Algeria, Angola, Antigua and Barbuda, Argentina, Armenia, Azerbaijan, Bahamas, Bangladesh, Belarus, Belize, Benin, Bhutan, Bolivia, Bosnia and Herzegovina, Botswana, Brazil, Bulgaria, Burkina Faso, Burundi, Cabo Verde, Cambodia, Cameroon, Central African Republic, Chad, Chile, China, Colombia, Comoros, Congo, Dem. Rep., Congo, Rep., Costa Rica, Cote d'Ivoire, Croatia, Dominica, Dominican Republic, Ecuador, Egypt, Arab Rep., El Salvador, Equatorial Guinea, Eritrea, Fiji, Gabon, Georgia, Ghana, Grenada, Guatemala, Guinea, Haiti, Honduras, India, Indonesia, Jordan, Kazakhstan, Kenya, Korea, Rep., Lao PDR, Latvia, Lebanon, Lesotho, Liberia, Libya, Lithuania, Macedonia FYR, Madagascar, Malawi, Malaysia, Maldives, Mali, Mauritius, Mexico, Moldova, Mongolia, Morocco, Mozambique, Namibia, Nepal, Nicaragua, Niger, Nigeria, Pakistan, Panama, Paraguay, Peru, Philippines, Romania, Russian Federation, Samoa, Senegal, Seychelles, Sierra Leone, Solomon Islands, South Africa, Sri Lanka, St. Kitts and Nevis, St. Lucia, St. Vincent and the Grenadines, Sudan, Swaziland, Tajikistan, Tanzania, Thailand, Togo, Tonga, Trinidad and Tobago, Tunisia, Turkey, Uganda, Ukraine, Uruguay, Venezuela RB, Vietnam, Zambia.”

\section{Results and Discussion}

\section{Descriptive statistics and regression results}

Descriptive statistics gives a summary and the basic topographies of the data in a study. It is merely the description of what is and what the selected sample shows.

Table 1 represents the pair-wise correlation matrix, to check the pair-wise correlation between all the economic growth variables and FDI for multicollinearity in the model. The values in the correlation matrix show the correlation between every two variables. Value with minus shows a negative relationship between these variables and vice versa. The range of the correlation coefficient is from 0 to 1 . The digit 1 indicates positively correlated, while in contrast, 0 represents no correlation. 
Table1: Correlation Matrix

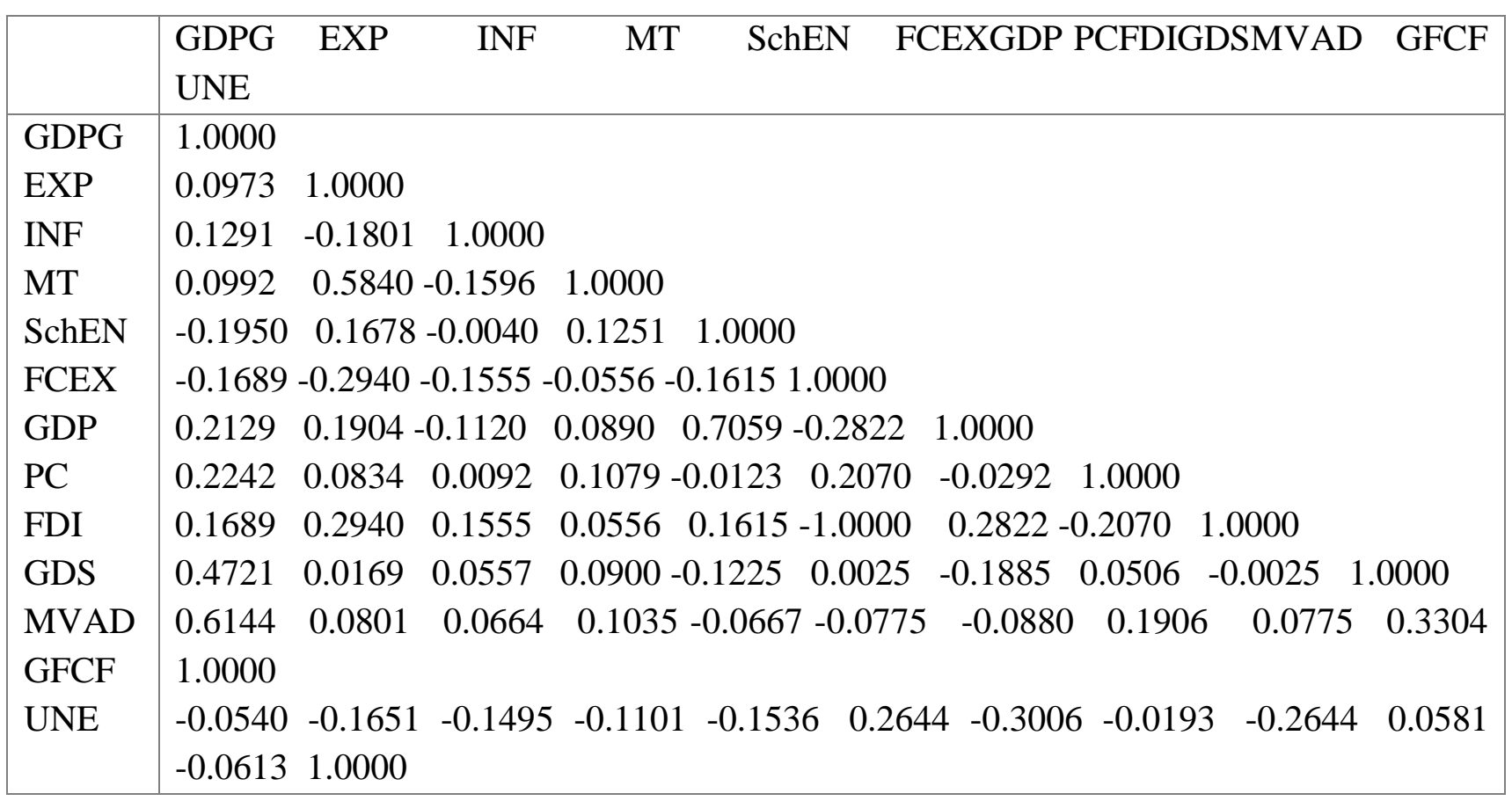

Table 2 presents the basic regression results, showing that FDI has a positive and significant relationship with GDP. An increase in FDI inflow will lead to increase in GDP growth. Similarly, CAB has positive relationship with GDP. Inflations showed a positive and significant relationship. UNE showed negative and insignificant relationship with GDP growth.

Table 2: Basic Regression Results

\begin{tabular}{ll}
\hline \multirow{2}{*}{ VARIABLES } & Model \\
\cline { 2 - 2 } FDI & GDP \\
\hline Inf & $0.134 * * *$ \\
& $(0.0246)$ \\
\hline CAB & $0.0400^{* * *}$ \\
& $(0.0152)$ \\
\hline GFCF & $0.0556^{* * *}$ \\
& $(0.0198)$ \\
\hline UNE & $0.143 * * *$ \\
& $(0.0226)$ \\
\hline Constant & -0.00753 \\
& $(0.0217)$ \\
\hline
\end{tabular}

Standard errors in parentheses

$* * * p<0.01, * * p<0.05, * p<0.1$ 


\section{Endogeneity Solutions}

Endogeneity occurs in a model when the independent variable is expected to have a relationship with other variables or error terms in the model. In other words, we can say the opposite of exogeneity. The relationship can be positive or negative. If endogeneity is not considered in the model, it will result in underestimating or overestimating the actual impact of the variable in the model.

\section{Endogeneity Check}

The (Durbin (score) and Wu- Hausman) test is performed to check the endogeneity. The p-value of both tests is more than 0.005. Based on the P-value, we reject the alternative hypothesis and accept the null hypothesis that variables are exogenous.

\section{Instrumental Variables regression (IV)}

IV regression method is used in the studies to control for baffling and estimation errors in the study (Angrist \& Krueger, 2001).It is necessary to select the appropriate instruments for the procedure based on the two main points criteria firstly the instruments must have a strong correlation with the endogenous variable. Secondly, the instrument has no relation with error terms.

Table 4 represents the first stage regression summary and critical values. to check whether the instruments are strong or weak. The test result indicates that the minimum eigenvalue (29.8107) is greater than the essential values given in the table. Based on the minimum Eigenvalue, we reject the null hypothesis that instruments are weak and accept the alternative that instruments are not weak.

Table 3: First stage regression summary

\begin{tabular}{|l|l|l|l|l|l|}
\hline Variables & R-sq & Adjusted R-sq & Partial R-sq & F $(2,180)$ & Prob > F \\
\hline FDI inflow & 0.4354 & 0.4103 & 0.488 & 29.8107 & 0.0000 \\
\hline
\end{tabular}

Minimum eigenvalue statistic $=29.8107$

Critical Values

Ho: Instruments are weak

2SLS relative bias

2SLS Size of nominal 5\% Wald test
\# of endogenous regressors: 1

\# of excluded instruments: 2

$5 \% \quad 10 \% \quad 20 \% \quad 30 \%$

(not available)

$\begin{array}{llll}19.93 & 11.59 & 8.75 & 7.25\end{array}$


Source: Author's calculation

Table 4 shows the result of Instrumental variables 2SLS regression. The instrumental variables are found in the previous literature; the same instruments were used by(Esiyok \& Ugur, 2015). The value of FDI inflow is positive and statistically significant. A unit change in FDI inflow will result in a 0.240 change in GDP growth of developing countries. Gross domestic savings (GDS) has also shown a positive and significant relationship with GDP growth. The school enrolment is negative and insignificant statistically. Unemployment has established a negative and significant relationship with developing countries' GDP growth as an expected sign of unemployment with the GDP growth of developing countries. The nexus between unemployment and GDP growth is always negative.

Table 4: Instrumental variable 2 SLS regression

\begin{tabular}{ll}
\hline \multirow{2}{*}{ VARIABLES } & Model \\
\cline { 2 - 2 } FDI inflow & GDP growth \\
\hline GDS & $0.240^{*}$ \\
& $(0.143)$ \\
\hline MVAD & $0.0653^{* * *}$ \\
& $(0.0159)$ \\
\hline DCBF & $0.379 * * *$ \\
& $(0.0336)$ \\
\hline UNE & -0.00392 \\
& $(0.00483)$ \\
\hline SchEN & $-0.0790 * * *$ \\
& $(0.0271)$ \\
\hline Constant & -0.0194 \\
& $(0.00944)$ \\
\hline Observations & $1.929 * * *$ \\
R-squared & $(0.685)$ \\
\hline Standard errors in parentheses & 190 \\
$* * * p<0.01, * * p<0.05, * p<0.1$ & 0.483 \\
\hline Instrumented: FDI inflow & \\
Instruments: corruption and the rule of law $($ Esiyok \& Ugur, 2015) & \\
Source: author's calculation &
\end{tabular}




\section{Test for over-identification}

The Sargan-Hansen, also called the Sargan J test used for testing over identifying in the model. The null hypothesis for the test is that;

\section{Ho: instruments are valid and the model correctly specified.}

The "Sargan and Basman" test results are performed to check the validity of instruments, including the model's specification with the null hypothesis that the set of instruments selected and used in the test is valid and the model is specified correctly. The test result accepts the null hypothesis based on the p- values and declares the test's validity and well specification.

Table 5: The test of over-identifying

\begin{tabular}{|l|l|l|}
\hline Sargan (score) chi2(1) & .000302 & $(\mathrm{p}=0.9861)$ \\
\hline Basmann chi2(1) & .000289 & $(\mathrm{p}=0.9864)$ \\
\hline
\end{tabular}

Source: Author's calculation

\section{Robustness test}

Table 6 represents the Hausman fixed effect results. There are two models reported in the model. GDP growth and GDP per capita are the indicators of a country's economic growth(Denison, 1962). This checked the relationship between GDP growth and FDI in the model (1), including some other control variables. In contrast, in Model (2), we incorporated the GDP per capita in place of GDP growth. The coefficient of FDI inflow percentage of GDP has a positive and significant relationship with both GDP growth and GDP per capita. The coefficient of inflation has a positive and statistically insignificant relationship with GDP growth. Many studies reported the importance of education for the economic growth of developing countries. The current results support the previous studies (Barro, 1991; Sala-I-Martin et al., 2004). The results show a positive and significant relationship between GDP growth and school enrolment.

Table 6: Robust check with changed measurement of GDP

\begin{tabular}{lll}
\hline & $\begin{array}{l}\text { Model } \\
(1)\end{array}$ & $\begin{array}{l}\text { Model } \\
(2)\end{array}$ \\
\hline VARIABLES & GDP growth & GDP per capita \\
\hline FDI\%GDP & $\begin{array}{l}0.173^{* * *} \\
(0.0295)\end{array}$ & $\begin{array}{l}0.186^{* * *} \\
(0.0377)\end{array}$ \\
\hline INF & 0.000679 & \\
& $(0.00932)$ & \\
\hline GFCF & $0.135^{* * *}$ & 0.0422 \\
& $(0.0263)$ & $(0.0361)$ \\
\hline CAB & $0.0756^{* * *}$ & \\
\hline SchEN & $(0.0215)$ & \\
\hline
\end{tabular}




\begin{tabular}{lll}
\hline & $(0.0128)$ & \\
\hline FCE & & $\begin{array}{l}-0.123^{* * * *} \\
(0.0263)\end{array}$ \\
\hline Trade\% of GDP & & $\begin{array}{l}0.0296^{* * *} \\
(0.0102)\end{array}$ \\
\hline R\&D & & $-1.295^{*}$ \\
& & $(0.709)$ \\
\hline Constant & $3.188^{* * *}$ & $10.09 * * *$ \\
& $(0.681)$ & $(2.736)$ \\
\hline Observations & 1,241 & 827 \\
R-squared & 0.602 & 0.121 \\
\hline Standard errors in parentheses & & \\
$* * * p<0.01, * * p<0.05, * p<0.1$ & & \\
Sources: Author's own calculation. & &
\end{tabular}

\section{Results}

The relationship between FDI and economic growth is not hidden from anyone. Inward FDI from developed/ advanced countries to developing countries contributes more than any other economic factor. FDI inflow has both macro and micro-level impacts on any developing economy. Endogenous growth theory says that FDI contributes to human capital, knowledge, and innovation of the developing world. Similarly, many more micro impacts inward FDI having. This study examined to check the role of inward FDI in developing countries' economic growth. As mentioned above, the study found a positive and significant relationship with developing countries' economic growth. Table 1 presents the pair-wise correlation among the study variables to summarize the dataset. The set of correlations did not exceed the value of 0.8 , which means the data has no multicollinearity problem. Table 2 reflects the basic regression.

Based on the p-value, we accepted the null hypothesis that there is no endogeneity problem in the model. Table 3 reports the result of the First stage regression summary. Table 4 represents the instrumental variables regression (2SLS). The result of the regression shows that FDI and GDP growth has a positive and significant relationship. This study supports the previous work by (Abbes et al., 2015; Nayyar and Mukherjee (2020); Bruhn et al. (2020)for a cluster of developing economies. The result also supports previous studies conducted for single countries (Sohail \& Mirza, 2020). Unemployment shows negative and significant results.

To check the robustness, this study changed the dependent variables and some control variables to see whether the result is robust. This study changed the regression method and found positive and significant results. Similarly, we changed the dependent variables of economic growth. We used GDP current US\$ and GDP per capita current US\$ in place of GDP growth and GDP per capita growth. Again this study found positive and significant results. Gross fixed capital formation, and education has positive and significant results. Inflation shows negative results and confirmed the expected sign of a negative relationship. This overall result supports Silajdzic 
and Mehic (2015)in which they emphasize that FDI plays a vital role in developing countries' economic growth. The benefits from the FDI depend upon the level of development of the recipient country. To benefit more from inward FDI, a country needs to improve its domestic investment level, infrastructure and the financial sector Adekunle et al. (2020).

\section{Conclusion and Suggestion}

The present study was carried out to check the relationship between FDI inflow and economic growth of developing countries. The impact of FDI inflow is not identical for each country. The ratio of FDI inflow is not the same too. Inflow ratio depends upon the host country policies, institutional sittings, and absorption level. Similarly, the impact of FDI depends upon the amount and type of FDI inflow. Previous studies including this study conclude that FDI inflow has positive impact on economic growth of developing economy. This situation is considered as pre COVID-19 world. The situation after COVID-19 is arguably different, and, therefore, future studies are directed to trace the relationship between FDI inflow and economic growth in post COVID-19.

\section{Conflict of Interest}

The authors declares no conflict of interest

\section{Funding}

None

\section{References}

Adekunle, I. A., Williams, T. O., Omokanmi, O. J., \& Onayemi, S. O. (2020). Mediating roles of institutions in the remittance-growth relationship: evidence from Nigeria: AGDI Working Paper.

Adhikary, B. K. (2017). Factors influencing foreign direct investment in South Asian economies: A comparative analysis. South Asian Journal of Business Studies, 6 (1), 837. https://doi.org/10.1108/SAJBS-10-2015-0070

Alam, A., \& Shah, S. Z. A. (2013). Determinants of foreign direct investment in OECD member countries. Journal of Economic Studies, 40 (4), 515-527. https://doi.org/10.1108/JES-102011-0132

Angrist, J. D., \& Krueger, A. B. (2001). Instrumental variables and the search for identification: From supply and demand to natural experiments. Journal of Economic perspectives, 15(4), 69-85.

Barro, R. J. (1991). Economic growth in a cross section of countries. The Quarterly Journal of Economics, 106(2), 407-443.

Bruhn, N. C. P., Calegario, C. L. L., \& Mendonça, D. (2020). Foreign direct investment in developing economies A study on the productivity spillover effects in Latin America. RAUSP Management Journal, 55(1), 40-54. 
De Mello Jr, L. R. (1997). Foreign direct investment in developing countries and growth: A selective survey. The journal of development studies, 34(1), 1-34.

Denison, E. F. (1962). Education, economic growth, and gaps in information. Journal of political economy, 70(5, Part 2), 124-128.

Esiyok, B., \& Ugur, M. (2015). A spatial regression approach to FDI in Vietnam to FDI in Vietnam. The Singapore Economic Review, 1550115.

Fagerberg, J., \& Sollie, G. (1987). The method of constant market shares analysis reconsidered. Applied Economics, 19(12), 1571-1583.

Gudaro, A. M., Chhapra, I. U., \& Sheikh, S. A. (2012). Impact of foreign direct investment on economic growth: A case study of Pakistan. IBT Journal of Business Studies (JBS), 8(2).

Iamsiraroj, S. (2016). The foreign direct investment-economic growth nexus. International Review of Economics \& Finance, 42, 116-133.

Kaldor, N. (1961). Capital accumulation and economic growth The theory of capital (pp. 177222): Springer.

Khaliq, A., \& Noy, I. (2007). Foreign direct investment and economic growth: Empirical evidence from sectoral data in Indonesia. Journal of Economic Literature, 45(1), 313325.

Kremer, M. (1993). The O-ring theory of economic development. The Quarterly Journal of Economics, 108(3), 551-575.

Lea, R. (2019). The IMF downgrades global growth again for 2019, slowest pace since the financial crisis. Growth, 130(7).

Mankiw, N. G., Romer, D., \& Weil, D. N. (1992). A contribution to the empirics of economic growth. The Quarterly Journal of Economics, 107(2), 407-437.

Nayyar, R., \& Mukherjee, J. (2020). Home country impact on Outward FDI from India. Journal of Policy Modeling, 42(2), 385-400.

Rehman, N. U. (2016). FDI and economic growth: empirical evidence from Pakistan. Journal of Economic and Administrative Sciences. 32 (1),63-76. https://doi.org/10.1108/JEAS-122014-0035

Romer, P. M. (1994). The origins of endogenous growth. Journal of Economic perspectives, 8(1), 3-22.

Sabir, S., Rafique, A., \& Abbas, K. (2019). Institutions and FDI: evidence from developed and developing countries. Financial Innovation, 5(1), 1-20.

Silajdzic, S., \& Mehic, E. (2015). Knowledge spillovers, absorptive capacities and the impact of FDI on economic growth: empirical evidence from transition economies. ProcediaSocial and Behavioral Sciences, 195, 614-623.

Sohail, S., \& Mirza, S. S. (2020). Impact of Foreign Direct Investment on Economic Growth of Pakistan. Asian Journal of Economics, Finance and Management, 2(3), 1-13.

Sokhanvar, M., \& Mahmoodi, N. (2015). Identifying and prioritizing the influential factors in the absorption of foreign direct investment the AHP model (Case Study: Kurdistan Province). Environment Conservation Journal, 16(Special Edition), 239-246.

Solow, R. M. (1957). Technical change and the aggregate production function. The review of Economics and Statistics, 39(3), 312-320.

Copyright (C) 2021, Journal of Advanced Research in Economics and Administrative Sciences (JAREAS), Under a Creative Commons Attribution 4.0 International License 
Stiglitz, J. E. (1999). The World Bank at the millennium. The Economic Journal, 109(459), F577-F597.

Tabassum, N., Kaleem, A., \& Nazir, M. S. (2013). Impact of real earnings management on subsequent financial performance. Middle-East Journal of Scientific Research, 17(4), $551-560$. 